\title{
UJI AKTIVITAS ANTIBAKTERI MINYAK ATSIRI DAUN SIRIH HIJAU (Piper betle L.) TERHADAP BAKTERI Streptococcus pyogenes dan Staphylococcus aureus
}

\section{Antibacterial Activity of the Essential Oil from Betel leaf (Piper betle L.) against Streptococcus pyogenes and Staphylococcus aureus}

\author{
Hernandi Sujono, Samsu Rizal, Sari Purbaya, dan Jasmansyah* \\ Jurusan Kimia, Fakultas Sains dan Informatika, Universitas Jenderal Achmad Yani, Jl. Terusan Jenderal \\ Sudirman PO BOX 148, Cimahi \\ *E-mail: jasmansyah@unjani.ac.id
}

DOI: https://doi.org/10.26874/jkk.v2i1.27

Received: 13 May 2019, Revised: 31 May 2019, Accepted: 31 May 2019, Online: 31 May 2019

\begin{abstract}
Abstrak
Daun sirih hijau (Piper betle L) merupakan suatu tanaman obat. Minyak atsiri daun sirih hijau memiliki aktivitas antibakteri dari senyawa fenolik dan turunannya. Streptococcus pyogenes dan Staphylococcus aureus merupakan bakteri yang dapat menyebabkan radang tenggorokan (faringitis). Penelitian ini dilakukan untuk mengetahui cara memperoleh minyak atsiri dari daun sirih hijau (Piper betle L.) menggunakan metoda destilasi uap-air dan mengetahui aktivitas antibakterinya terhadap bakteri Streptococcus pyogenes dan Staphylococcus aureus menggunakan metode sumuran. Daun sirih hijau sebanyak $5 \mathrm{~kg}$ diisolasi menggunakan destilasi uap-air menghasilkan minyak atsiri sebanyak $9 \mathrm{~mL}$, dengan rendemen $0,135 \%$, bobot jenis $0,750 \mathrm{~g} / \mathrm{mL}$, dan indeks bias 1,337. Adapun hasil analisis GCMS minyak atsiri daun sirih hijau diperoleh 10 senyawa dominan yaitu senyawa kavikol, eugenol, germacren D, karyofilen, eugenol asetat, 2-alifenol, $\beta$-chamigren, $\alpha$-kadinen, terpineol, dan $\alpha$-humulen. Hasil uji aktivitas antibakteri dari minyak atsiri daun sirih hijau pada kosentrasi 10\%, 20\%, 30\%, dan 40\% dapat menghambat bakteri Streptococcus pyogenes dan Staphylococcus aureus dengan kategori hambatan lemah sampai sedang untuk bakteri Streptococcus pyogenes dan kategori hambatan lemah sampai kuat untuk bakteri Staphylococcus aureus.
\end{abstract}

Kata Kunci: Antibakteri, daun sirih hijau, metode sumuran, Streptocoocus pyogenes, Staphylococcus aureus

\section{Abstract}

Betel leaf (Piper betle L) is a medicinal plant. Its essential oil has antibacterial activity of phenolic compounds and theirs derivatives that can inhibit a wide range of bacteria. Streptococcus pyogenes and Staphylococcus aureus is a bacteria that can cause strep throat (pharyngitis). This study was conducted to determine how to obtain the essential oil of Betel leaf green (Piper betle L.) using steam-water distillation method and determine the antibacterial activity of essential oils of betel leaf (Piper betle L.) against the bacteria Streptococcus pyogenes and Staphylococcus aureus using wells method. Betel leaf $5 \mathrm{~kg}$ isolated using steam-water distillation of essential oils produces as much as $9 \mathrm{~mL}$, yield of $0.135 \%$, a specific gravity of $0.750 \mathrm{~g} / \mathrm{mL}$, and the refractive index of 1.337. The results of GC-MS analysis of betel leaf green essential oil obtained 10 Most compounds are compounds chavicol, eugenol, germacrene D, caryophyllen, eugenol acetate, 2-allyphenol, $\beta$-chamigrene, $\alpha$-cadinene, terpineol, and $\alpha$-humulene. Based on the test results of the antibacterial activity of betel leaf that the essential oil of betel leaf green (Piper betle L) at the concentration of 10\%, 20\%, 30\%, and 40\% can inhibit the bacteria Streptococcus pyogenes and Staphylococcus aureus, the category of barriers weak to moderate for 
bacteria Streptococcus pyogenes and weak to strong resistance categories for Staphylococcus aureus bacteria.

Keywords: Antibacterial, Piper betle L, Staphylococcus aureus, Streptococcus pyogenes, wells method

\section{Pendahuluan}

Tumbuhan merupakan sumber yang sangat penting bagi manusia dalam menjalani kehidupan [1]. Piper betle L merupakan suatu tanaman obat yang memiliki manfaat, baik untuk kesehatan, pencegahan dan pengobatan berbagai penyakit. Daun sirih hijau mengandung berbagai macam senyawa fenolik dan turunannya serta dapat berguna dalam menyembuhkan radang tenggorokan (faringitis) [2].

Bakteri yang terdapat di tenggorokan dan menyebabkan faringitis diantaranya adalah Staphylococcus aureus [2]. Selain Staphylococcus aureus, faringitis disebabkan juga oleh bakteri Streptococcus pyogenes [3]. Kedua bakteri ini merupakan bakteri Gram positif yang merupakan bakteri patogen bagi manusia [4].

Khasiat antibakteri daun sirih hijau telah dilaporkan [5], mengenai aktivitas antibakteri ekstrak sirih hijau (Piper betle L.) terhadap bakteri patogen pangan [6], pengujian aktivitas antibakteri dari minyak atsiri yang berasal dari daun sirih hijau (Piper betle L.) terhadap pertumbuhan bakteri Staphylococcus aureus dan bakteri gram positif E.coli menggunakan metode paper disc method dan TSA sebagai media dan menentukan kandungan komponen penyusun minyak atsiri dari daun sirih hijau (Piper betle L.). menggunakan analisis Gas ChromatographyMass Spectrometry (GC-MS).

Penelitian tentang bakteri Streptococcus pyogenes pernah dilakukan [7], dengan judul penelitian Uji efek antibakteri ekstrak kulit kayu manis (Cinnamomum burmannii) terhadap Escherichia coli dan Streptococcus pyogenes, bahwa kayu manis (Cinnamomum burmannii) memiliki efek antibakteri terhadap bakteri Escherichia coli dan Streptococcus pyogenes.

Penelitian menggunakan metode sumuran pernah dilakukan oleh [8], dengan judul penelitian yaitu, daya hambat ekstrak daun sirih merah (piper crocatum) terhadap Streptococcus mutans.

Daun sirih hijau (Piper betle L.) saat ini banyak dimanfaatkan untuk pengobatan alami, salah satunya mengobati radang tenggorokan (faringitis). Kebanyakan dalam kehidupan seharihari, pengobatan faringitis sering kali menggunakan obat antiobiotik seperti amoxicillin, siprofloksasin. Namun penggunaan antiobiotik sendiri memiliki efek samping karena dosisnya yang cukup tinggi. Maka dari itu, berdasarkan latar belakang di atas perlu dilakukan penelitian lebih lanjut tentang uji aktivitas antibakteri minyak atsiri daun sirih hijau (Piper betle L) terhadap bakteri Streptococcus pyogenes dan Staphylococcus aureus.

\section{Metode Penelitian}

2.1 Pengambilan minyak atsiri daun sirih hijau Cuci daun sirih hijau dengan air sampai bersih. kemudian setelah dicuci, masukan daun sirih hijau ke dalam stainlees steel pada alat destilasi uap air. Tambahkan aquades secukupnya.Alirkan uap air pada tumpukan daun sirih hijau sampai didapatkan minyak atsiri secara maksimal. Minyak atsiri yang telah didapatkan kemudian tambahkan dengan $\mathrm{Na}_{2} \mathrm{SO}_{4}$ anhidrat. Selanjutnya lakukan dekantasi agar didapatkan minyak atsiri murni tanpa kandungan air.

Minyak atsiri yang telah murni tanpa kandungan air kemudian dibagi menjadi dua bagian. Lakukan uji GC-MS untuk sebagian dari minyak atsiri untuk mengetahui kandungan minyak atsiri daun sirih hijau dan untuk menguji aktivitas antibakteri minyak atsiri daun sirih hijau terhadap bakteri Streptococcus pyogenes dan Staphylococcus aureus.

\subsection{Pembuatan variasi konsentrasi minyak atsiri daun sirih hijau}

Minyak daun sirih hijau yang diperoleh dari hasil proses destilasi uap-air, diencerkan menggunakan DMSO (dimetil sulfoksida) dengan 4 variasi konsentrasi $(10 \%, 20 \%, 30 \%$, $40 \%)$.

\subsection{Kultur bakteri Streptococcus pyogenes dan Staphylococcus aureus}

Pembuatan stok bakteri ini dilakukan untuk memperbanyak dan meremajakan bakteri, dengan cara menginokulasikan 1 ose biakan murni bakteri Streptococcus pyogenes ke dalam cawan petri yang berisi Mueller-Hinton Agar Darah. Sedangkan untuk bakteri Staphylococcus aureus, menginokulasikan 1 ose biakan murni ke dalam tabung reaksi yang berisi Mueller-Hinton Agar. kemudian masing-masing diinbukasi pada suhu $37^{\circ} \mathrm{C}$ selama 24 jam di dalam inkubator. 


\subsection{Uji aktivitas antibakteri minyak daun sirih hijau terhadap bakteri Streptococcus pyogenes}

Bakteri diencerkan dengan mencampurkan 1 ose suspensi bakteri Streptococcus pyogenes ke dalam tabung reaksi yang telah berisi larutan $\mathrm{NaCl}$. Homogenkan dengan cara di goyang dan kekeruhannya distandarisasi dengan konsentrasi Mc Farland 0,5 sehingga jumlah bakteri memenuhi standarisasi untuk uji kepekaan yaitu : $105-108$ / ml. Kemudian larutan bakteri yang telah distandarisasi tadi, dioleskan pada media pertumbuhan MHA Darah menggunakan swab kapas steril. Pada media MHA Darah dibuat lubang sumuran sebanyak 6 lubang untuk diberi perlakuan hasil pengenceran minyak daun sirih hijau menggunakan DMSO (dimetil sulfoksida) dengan konsentrasi 10\%, 20\%, 30\%, dan $40 \%$ serta aquadest sebagai kontrol negatif dan siprofloksasin $0,2 \%$ sebagai kontrol positif. Inkubasi ke dalam inkubator dengan suhu $37^{\circ} \mathrm{C}$ selama 24 jam.

Amati dan ukur daerah zona hambatnya yang terbentuk disekitar lubang menggunakan jangka sorong. Perlakuan dilakukan secara duplo.

\subsection{Uji Aktivitas Antibakteri Minyak Daun Sirih Hijau Terhadap Bakteri Staphylococcus aureus}

Bakteri diencerkan dengan mencampurkan 1 ose suspensi bakteri Staphylococcus aureus ke dalam tabung reaksi yang telah berisi larutan $\mathrm{NaCl}$. Homogenkan dengan cara di goyang dan kekeruhannya distandarisasi dengan konsentrasi 0,5 Mc Farland sehingga jumlah bakteri memenuhi standarisasi untuk uji kepekaan yaitu : 105-108/ml. Kemudian larutan bakteri yang telah distandarisasi tadi, dioleskan pada media pertumbuhan MHA menggunakan swab kapas steril. Pada media MHA dibuat lubang sumuran sebanyak 6 lubang untuk diberi perlakuan hasil pengenceran minyak daun sirih hijau menggunakan DMSO (dimetil sulfoksida) dengan konsentrasi 10\%, 20\%, 30\%, dan $40 \%$ serta aquadest sebagai kontrol negatif dan siprofloksasin $0,2 \%$ sebagai kontrol positif. Inkubasi ke dalam inkubator dengan suhu $37^{\circ} \mathrm{C}$ selama 24 jam. Amati dan ukur daerah zona hambatnya yang terbentuk disekitar lubang menggunakan jangka sorong. Perlakuan dilakukan secara duplo.

\subsection{Uji Penegasan Bakteri Streptococcus pyogenes \\ Siapkan media MHA Darah. Bakteri yang} sudah distandarisasi, oleskan menggunakan swab kapas steril pada media MHA Darah.Inkubasi ke dalam inkubator dengan suhu $37^{\circ} \mathrm{C}$ selama 24 jam dan amati. Apabila darah pada media MHA Darah terhemolisis, maka bakteri tersebut positif Streptococcus pyogenes.

\subsection{Uji Penegasan Bakteri Staphylococcus aureus}

Siapkan media MSA. Bakteri yang sudah distandarisasi, oleskan menggunakan swab kapas steril pada media MSA. Inkubasi ke dalam inkubator dengan suhu $37^{\circ} \mathrm{C}$ selama 24 jam dan amati. Apabila warna merah muda pada media MSA berubah menjadi warna kuning, maka bakteri tersebut positif Staphylococcus aureus.

\section{Hasil dan Diskusi}

Daun sirih hijau (Piper betle L.) pada penelitian ini di peroleh dari daerah Sindang Kerta Kec. Cimanggu Kabupaten Bandung Barat. Sindang kerta berada di daerah penggunungan/dataran tinggi. Sampel yang digunakan pada penelitian ini yaitu sebanyak 5 $\mathrm{kg}$. Kemudian $5 \mathrm{~kg}$ daun sirih hijau tersebut di destilasi menggunakan teknik destilasi uap-air. Dimana dari $5 \mathrm{~kg}$ daun sirih hijau tersebut menghasilkan minyak atsiri sebanyak $9 \mathrm{~mL}$, persen rendemen sebesar $0,135 \%$, bobot jenis sebesar $0,750 \mathrm{~g} / \mathrm{mL}$, dan indeks bias sebesar 1,337 .

Berdasarkan literatur \% rendemen minyak daun sirih hijau yaitu sebesar 0,53 \% [9], \% Rendemen yang diperoleh tidak sesuai yang ada pada literatur. Hal disebabkan oleh beberapa faktor diantaranya, iklim, kesuburan tanah, umur tanaman, dan cara penyulingan [10].

Bobot jenis standar minyak atsiri daun sirih hijau antara lain berkisar antara 0,958-1,057 $\mathrm{g} / \mathrm{mL}$ [11]. Dari Bobot jenis yang peroleh tidak masuk ke dalam rentang nilai standar. Hal ini disebabkan oleh beberapa faktor diantaranya adalah temperatur, massa minyak, volume minyak, dan kekentalan.

Indeks bias standar tanaman famili Piperaceae yaitu 1,496-1,529 [12]. Indeks bias yang diperoleh tidak masuk ke dalam rentang nilai standar. Hal ini dikarenakan, minyak yang diperoleh diperkirakan masih mengandung air dan dipengaruhi oleh suhu. Sehingga nilai indeks bias yang diperoleh kecil. 


\subsection{Hasil Uji GC-MS Minyak atsiri daun sirih hijau}

Dari hasil analisis GC-MS minyak atsiri daun sirih hijau (Piper betle L) dihasilkan 10 senyawa terbanyak dari 38 senyawa yaitu diantaranya 5 senyawa turunan fenol (senyawa kavikol $(21,27 \%)$, eugenol $(13,30 \%)$, eugenol asetat $(8,34 \%), 2$-alifenol $(7,01 \%)$, dan terpineol $(2,87 \%)$ ) dan 5 senyawa seskuiterpen (germacren D $(9,08 \%)$, karyofilen $(8,37 \%)$, beta-chamigren $(4,62 \%)$, alfa-kadinen $(3,88 \%)$, dan alfa-humulen $(2,42 \%)$. Hasil analisis GCMS minyak atsiri daun sirih hijau tersebut sesuai dengan literatur.

\subsection{Hasil uji aktivitas antibakteri minyak atsiri daun sirih hijau terhadap bakteri Streptococcus pyogenes}

Hasil uji aktivitas antibakteri minyak atsiri daun sirih hijau dibandingkan dengan kontrol positif dan negatifnya terhadap bakteri Streptococcus pyogenes diperlihatkan pada Tabel 1 dan Gambar 1. Berdasarkan hasil tersebut, masing-masing variasi konsentrasi minyak atsiri daun sirih hijau dapat menghambat pertumbuhan bakteri Streptococcus pyogenes dan hambatanya dikategorikan ke dalam hambatan lemah sampai sedang (Tabel 3).

\subsection{Hasil Uji Aktivitas Antibakteri Minyak Daun Sirih Hijau Terhadap Bakteri Staphylococcus aureus}

Hasil uji aktivitas antibakteri minyak atsiri daun sirih hijau dibandingkan dengan kontrol positif dan negatifnya terhadap bakteri Bakteri Staphylococcus aureus diperlihatkan pada Tabel 2 dan Gambar 2. Berdasarkan hasil tersebut, masing-masing variasi konsentrasi minyak atsiri daun sirih hijau dapat menghambat pertumbuhan bakteri Staphylococcus aureus dan hambatanya dikategorikan ke dalam hambatan lemah sampai kuat (Tabel 3).

\subsection{Hubungan konsentrasi dan kandungan} minyak atsiri terhadap aktivitas antibakteri

Untuk hasil uji aktivitas antibakteri minyak atsiri daun sirih hijau (Piper betle L) dengan variasi konsentrasi minyak sebesar $10 \%, 20 \%$, $30 \%$, dan $40 \%$ terbukti dapat menghambat pertumbuhan bakteri Streptococcus pyogenes dan Staphylococcus aureus. Semakin besar konsentrasi maka akan semakin besar pula daya hambat terhadap bakteri Streptococcus pyogenes dan Staphylococcus aureus.Yang menjadikan perbedaan hasil uji aktivitas antibakteri terhadap bakteri Streptococcus pyogenes maupun Staphylococcus aureus yaitu resistensi dari bakterinya itu sendiri terhadap suatu antibiotik atau antibakteri [6].

Adapun klasifikasi respon hambatan pertumbuhan bakteri menurut Greenwood dalam jurnal [13], tentang Pengaruh Pemberian Ekstrak Daun Sirih (Piper betle L.) Terhadap Pertumbuhan Staphylococcus aureus Isolat Dari Penderita Faringitis ditunjukkan dalam Tabel 3.

Selain hambatan dari minyak atsiri daun sirih hijau, dilakukan pula penghambatan menggunakan antibiotik siprofloksasin 0,2 \% sebagai kontrol +. Dari hasil hambatan tersebut, menunjukan hambatan yang kuat, lebih dari 20 mm, baik terhadap bakteri Streptococcus pyogenes maupun bakteri Staphylococcus aureus. Hambatan minyak atsiri daun sirih hijau mulai efektif menghambat bakteri Streptococcus pyogenes maupun Staphylococcus aureus, yaitu berada pada konsentrasi minyak atsiri daun sirih hijau sebesar $20 \%$ atau $>20 \%$. Hal ini karena dengan penggunaan konsentrasi mulai dari $20 \%$ atau > $20 \%$ bisa menghasilkan hambatan kategori sedang sampai kuat.

Daya antibakteri minyak atsiri daun sirih hijau disebabkan oleh adanya senyawa fenol dan turunannya yang dapat mendenaturasi protein sel bakteri[9]. Selain merusak dinding sel, senyawa fenol dan turunannya dapat mendenaturasi protein sel dan merusak membran sel [14]. Pada konsentrasi tinggi fenol dapat merusak membran sitoplasma secara total [15]. Selain fenol, beberapa hasil penelitian lain menunjukkan bahwa senyawa terpenoid juga dapat menghambat pertumbuhan bakteri yaitu dengan mengganggu proses terbentuknya membran atau dinding sel, membran atau dinding sel tidak terbentuk atau terbentuk tidak sempurna [16].

Dengan keberadaan senyawa turunan fenolik dan senyawa terpenoid (seskuiterpen) dari minyak atsiri daun sirih hijau, hal ini dapat merusak dinding sel, mendenaturasi protein sel dan merusak membran sel bakteri Streptococcus pyogenes dan Staphylococcus aureus. Selain itu juga dapat menghambat pertumbuhan bakteri yaitu dengan mengganggu proses terbentuknya membran atau dinding sel, membran atau dinding sel tidak terbentuk atau terbentuk tidak sempurna. Sehingga hal ini, dari 10 senyawa terbesar hasil GC-MS minyak atisiri daun sirih hijau, terbukti kuat dapat menghambat bakteri Streptococcus pyogenes dan Staphylococcus 
aureus. Adapun 10 senyawa tersebut antara lain, 5 senyawa turunan fenol (senyawa kavikol $(21,27$ $\%)$, eugenol $(13,30 \%)$, eugenol asetat $(8,34 \%)$, 2-alifenol (7,01\%), dan terpineol $(2,87 \%))$ dan 5 senyawa seskuiterpen ( (germacren D $(9,08 \%)$, karyofilen $(8,37 \%)$, beta-chamigren $(4,62 \%)$, alfa-kadinen $(3,88 \%)$, dan alfa-humulen $(2,42$ \%)).

Tabel 1. Hasil uji aktivitas antibakteri minyak atsiri daun sirih hijau terhadap bakteri Streptococcus pyogenes

\begin{tabular}{lccc}
\hline \multirow{2}{*}{$\begin{array}{c}\text { Konsentrasi Minyak } \\
\text { Atsiri }\end{array}$} & \multicolumn{3}{c}{$\begin{array}{c}\text { Diameter Zona } \\
\text { Hambat }\end{array}$} \\
\cline { 2 - 4 } & I mm) \\
\hline $10 \%$ & 13,3 & 14,3 & 13,8 \\
$20 \%$ & 15,4 & 16,4 & 15,9 \\
Rata- \\
$30 \%$ & 17,4 & 17,4 & 17,4 \\
$40 \%$ & 18,4 & 19,3 & 18,85 \\
Kontrol & & & \\
(+) Siprofloksasin $0,2 \%$ & 34,3 & 34,6 & 34,45 \\
(-) Aquadest & 0 & 0 & 0 \\
\hline
\end{tabular}
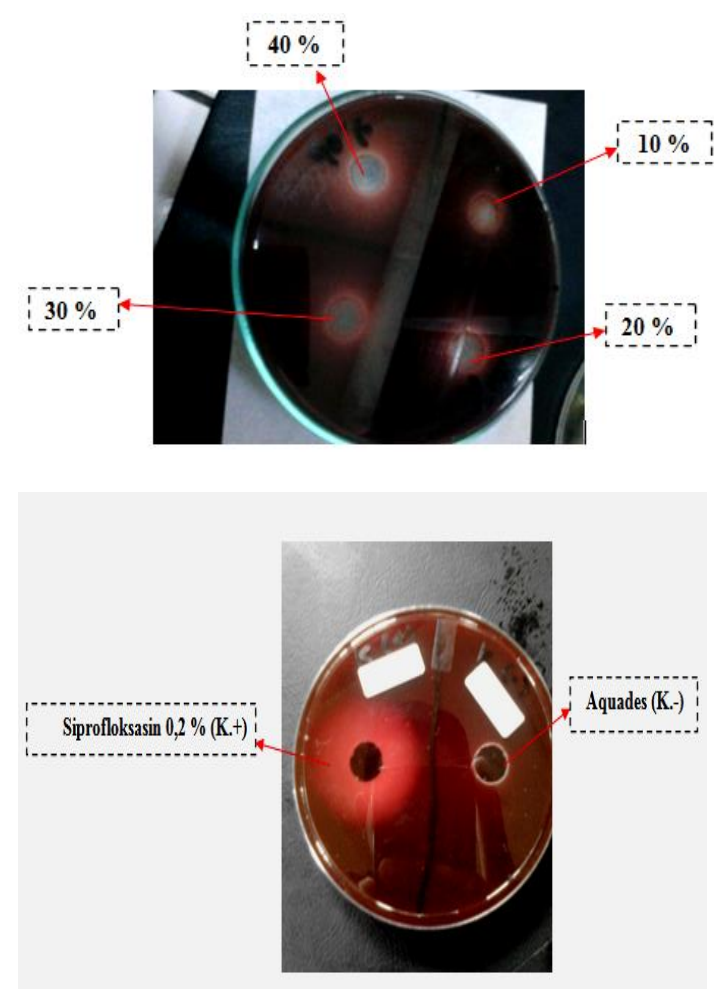

Gambar 1. Zona hambat hasil uji aktivitas antibakteri terhadap bakteri Streptococcus pyogenes menggunakan: a) minyak atsiri daun sirih hijau 10\%, 20\%, 30\%, $40 \%$ dan b) Siprofloksasin $0,2 \%$ sebagai kontrol positif dan aquadest sebagai kontrol negatif
Tabel 2. Hasil uji aktivitas antibakteri minyak atsiri daun sirih hijau terhadap bakteri Staphylococcus aureus

\begin{tabular}{lccc}
\hline \multirow{2}{*}{$\begin{array}{c}\text { Konsentrasi Minyak } \\
\text { Atsiri }\end{array}$} & \multicolumn{3}{c}{$\begin{array}{c}\text { Diameter Zona } \\
\text { Hambat (mm) }\end{array}$} \\
\cline { 2 - 4 } & I & II & $\begin{array}{c}\text { Rata- } \\
\text { Rata }\end{array}$ \\
\hline $10 \%$ & 13,4 & 14,3 & 13,85 \\
$20 \%$ & 17,3 & 17,9 & 17,6 \\
$30 \%$ & 20,3 & 21,4 & 20,85 \\
$40 \%$ & 23,4 & 24,4 & 23,9 \\
Kontrol & & & \\
(+) Siprofloksasin $0,2 \%$ & 43,3 & 43,6 & 43,45 \\
(-) Aquadest & 0 & 0 & 0 \\
\hline
\end{tabular}
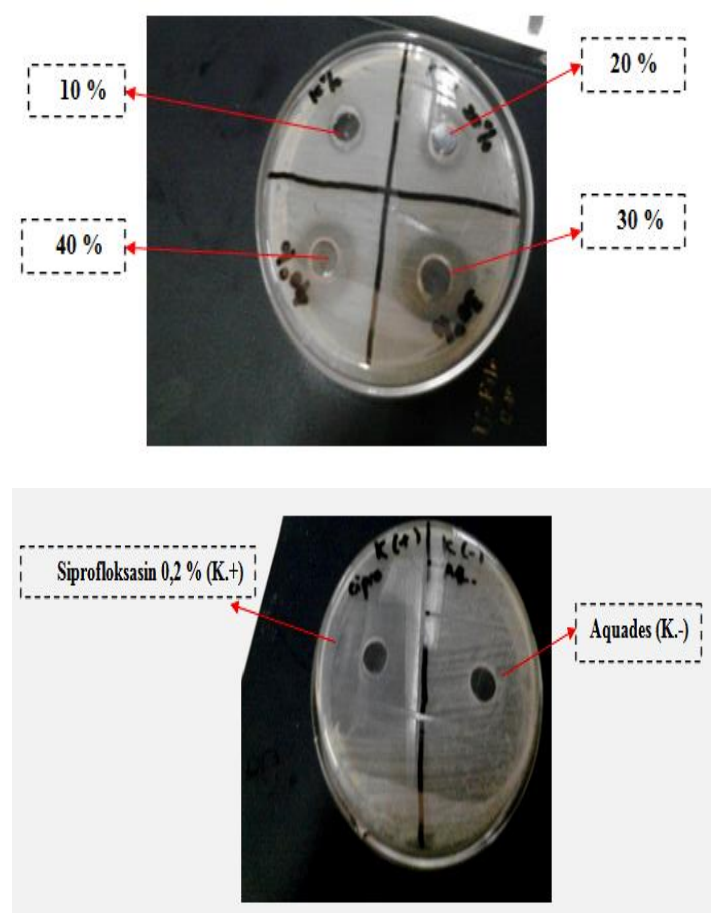

Gambar 2. Zona hambat hasil uji aktivitas antibakteri terhadap bakteri Staphylococcus aureus menggunakan: a) minyak atsiri daun sirih hijau 10\%, 20\%, 30\%, 40\% dan b) Siprofloksasin $0,2 \%$ sebagai kontrol positif dan aquadest sebagai kontrol negatif

Tabel 3. Kategori respon hambatan pertumbuhan bakteri

\begin{tabular}{cc}
\hline $\begin{array}{c}\text { Diameter Zona } \\
\text { Hambat }(\mathbf{m m})\end{array}$ & $\begin{array}{c}\text { Respon Hambatan } \\
\text { Pertumbuhan }\end{array}$ \\
\hline$>20$ & Kuat \\
$16-20$ & Sedang \\
$1-15$ & Lemah \\
0 & Tidak Ada \\
\hline
\end{tabular}


3.5 Hasil Uji Penegasan Bakteri Streptococcus pyogenes dan Staphylococcus aureus

Pada uji penegesan bakteri ini, bertujuan untuk membuktikan bahwa bakteri yang digunakan adalah betul-betul bakteri Streptococcus pyogenes dan Staphylococcus aureus. Di mana untuk membuktikan bakteri Streptococcus pyogenes, Uji positif bakteri Streptococcus pyogenes yaitu warna merah darah pada media MHA Darah akan terhemolisis seperti Gambar 3 Sedangkan untuk membuktikan bakteri Staphylococcus aureus, Uji positif bakteri Staphylococcus aureus yaitu warna merah muda pada media MSA berubah warna menjadi warna kuning seperti Gambar 4.

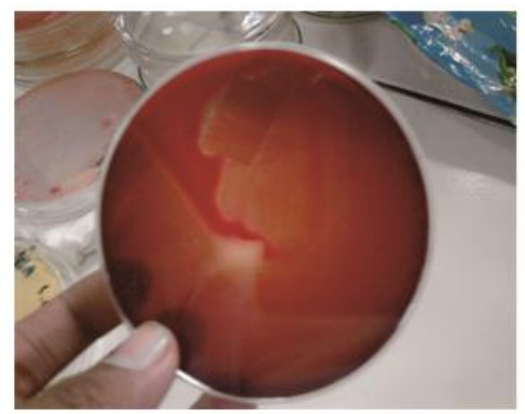

Gambar 3. Hasil uji penegasan bakteri Streptococcus pyogenes

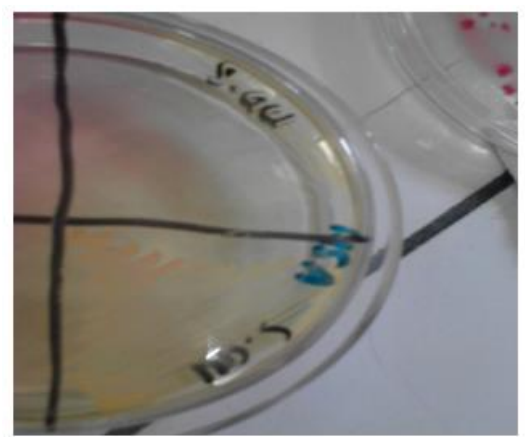

Gambar 4. Hasil uji penegasan bakteri Staphylococcus aureus

\section{Kesimpulan}

Pengambilan Minyak atsiri dari daun sirih hijau (Piper betle L.) dapat diperoleh dengan metode destilasi uap-air dan diperoleh juga persen rendemen sebesar $0,135 \%$, bobot jenis $0,750 \mathrm{~g} / \mathrm{mL}$, dan indeks bias 1,337 . Berdasarkan hasil GC-MS, 10 senyawa terbanyak terdiri dari 5 senyawa turunan fenol dan 5 senyawa seskuiterpen. Minyak atsiri daun sirih hijau (Piper betle L) dapat menghambat bakteri Streptococcus pyogenes dan Staphylococcus aureus.

\section{Daftar Pustaka}

[1] Sudewo, B. 2004. Tanaman Obat Populer Penggempur Aneka Penyakit. Agromedia Pustaka. Jakarta.

[2] Gupte, S.1990. Mikrobiologi Dasar Edisi Ketiga. Terjemahan dari The Textbook of Medical Microbiology, oleh J. E. Suryawidjaja. Binarupa Aksara. Jakarta.

[3] Dorland, W.A.N. 2010. Kamus kedokteran dorland. Edisi 31. EGC. Hal. 1238-1239.

[4] Hermawan,A., Hana, W. dan Wiwiek, T. 2007. Pengaruh Ekstrak Daun Sirih (Piper betle L.) Terhadap Pertumbuhan Staphylococcus aureus dan Escherichia Coli dengan Metode Diffusi Disk. UNAIR. Surabaya.

[5] Suliantri, B.S.L.Jenie, M.T Suhartono, dan A. Apriyantono. Aktivitas Antibakteri Ekstrak Sirih Hijau (Piper Betle L) Terhadap Bakteri Patogen Pangan. Jurnal Teknol dan Industri Pangan, Vol. XIX No.1 Th.2008.

[6] Rachmat, Masykur, Mae Sri Hartini W, dan Subagus Wahyuono. Aktivitas Antibakteri sediaan obat kumur berisi minyak atsiri daun sirih (Piper Betle Linn) dan Analisis Komposisi Minyak Atsirinya. 2000. Majalah Farmasi Indonesia, Vol. 11(4), Hal. 235-240.

[7] Repi, Christi Mambo, dan Jane Wuisan. Uji efek antibakteri ekstrak kulit kayu manis Terhadap Pertumbuhan Staphylococcus aureus Isolat dari Penderita Faringitis. Loka Penelitian dan Pengembangan Biomedis Aceh, SEL Vol. 2 No. 2 November 2015: 57-65.

[8] Wahyu, N Qolifah Indah, Pujiana Endah Lestari, dan Erna sulistyani. Daya Hambat Ekstrak Daun Sirih Merah (Piper crocatum) terhadap Streptococcus mutans. Jurnal Hasil Penelitian Mahasiswa, 2013.

[9] Harapini, M., Agusta, A., dan Rahayu, R. D. 1996. Analisis Komponen Kimia Minyak Atsiri dari Dua Macam Sirih (Daun Sirih Kuning dan Hijau), Prosiding Simposium Nasional I Tumbuhan Obat dan Aromatika. Hal. 58-64.

[10] Ketaren, S. 1985. Pengantar Teknologi Minyak Atsiri. Jakarta. Balai Pustaka.

[11] Guenther, E. 1952. The Essential Oils. Volume Two, Fourth Printing, Van 
Nostrand Reinhold Company. New York. Hal. 504-515.

[12] Gunther, E., 1987. Minyak Atsiri. Jilid I. Penerbit Universitas Indonesia. Jakarta.

[13] Effa dan Nona Rahmaida Puetri. Pengaruh Pemberian Ekstrak Daun Sirih (Piper betle L.) Terhadap Pertumbuhan Staphylococcus aureus Isolat dari Penderita Faringitis. Loka Penelitian dan Pengembangan Biomedis Aceh, SEL Vol. 2 No. 2 November 2015: 57-65.
[14] Pelczar. M. J., dan Chan, E. S. 1986. Dasar - Dasar Mikrobiologi. UI Press. Jakarta.

[15] Volk dan Wheeler. 1988. Mikrobiologi Dasar. Edisi Kelima. Jilid I. Penerbit Erlangga. Jakarta.

[16] Markham, KR. 2012. Cara mengidentifikasi flavanoid. Indonesia Medicus Veterinus, Vol. 1. No. 3. Hal. 337-51. 